\title{
Genetic parameters estimation in common bean under weed plant competition ${ }^{1}$
}

\author{
Clever Geraldo Coelho ${ }^{2}$, Leandro Pin Dalvi', Tiago de Souza Marçal ${ }^{3}$, \\ Lidiane dos Santos Gomes Oliveira ${ }^{\mathbb{D}}$, Fabio Luiz Oliveira ${ }^{2}$, Gustavo Sessa Fialho ${ }^{4}$
}

10.1590/0034-737X202168040011

\begin{abstract}
The present study aimed to estimate genetic parameters of 20 common bean genotypes, commercial and regional bean on weed interference. The agronomic characters analyzed were: average stem diameter (ASD); average plant length (APL); number of pods per pot (NPP); number of locules per pod (NLP); number of grains per pod (NGP); percentage of empty locules (\% EL); total grains per pot (TGP); total grain weight per pot (TGW) and average grain weight (AGW). High heritability values were found for most of the characters studied, except for NGP and EL; in addition to great genetic variability among genotypes. Therefore, for most of the characteristics of agronomic interest studied, simple selection methods can be applied with great potential to identify superior genotypes and consequent genetic progress in common bean breeding.
\end{abstract}

Keywords: Phaseolus vulgaris L.; Commelina diffusa L.; breeding.

\section{INTRODUCTION}

Currently, the common bean (Phaseolus vulgaris L.) Brazilian production is estimated at 3 million metric tons, which corresponds to approximately $10 \%$ of the world harvest and places the country in third place in the producers world ranking, behind only India and Myanmar, respectively (CONAB, 2020; FAOSTAT, 2020).

Common bean are also one of the main sources of protein in the Brazilian food base of low-income people especially. What makes this crop of great importance for the country agribusiness at economic and social levels (Prolla et al., 2010).

Thus, improve productivity, biofortification and ability to compete with weed plants are the current demands of the species, which can be achieved through plant breading and improvment of crop practices.

In addition, common bean have been cultivated in all Brazilian states, at different times (harvest and off-season), crop systems, soils and climatics conditions. This species also has a short vegetative cycle, on average 90 days for most cultivars, making it very sensitive to the interference of weed plants (Gomes et al., 2017). This competition can lead to huge losses, contributing to significant drops on productivity in the order of $67 \%$, as reported by Tavares et al. (2013).

In Brazil, Commelina diffusa L., also known as dayflower, is considered one of the main weed plants. Due to its efficient reproduction capacity, survival to adverse conditions and difficulty in control. The specie is an herbaceous plant, annual or perennial that settles in cultivated areas, preferably in humid soils and shaded environments. Due to the high water concentration in its tissues, it is able to survive even under water stress, which combined with its easy propagation and tolerance to various herbicides makes control difficult (Lorenzi et al., 2014).

This way, it is essential to search for common bean genotypes that present satisfactory performance under weed plants interference such as dayflower, aiming at crop sustainability. This can be done by exploring the genetic

\footnotetext{
Submitted on June 1st, 2020 and accepted on December 21st, 2020.

${ }^{1}$ This written work is parto $\mathrm{f}$ the first author's master's thesis. This study was financed in part by the Fundação de Amparo à Pesquisa e Inovação do Espírito Santo (FAPES).

${ }^{2}$ Universidade Federal do Espírito Santo, Departamento de Agronomia, Alegre, Espírito Santo, Brazil. clevercoelho2010@hotmail.com, leandropin@yahoo.com.br, lidianegomes31@gmail.com, fabiocapi@yahoo.com.br

${ }^{3}$ Universidade Federal de Lavras, Departamento de Biologia, Lavras, Minas Gerais, Brazil. tiago.marcal@ufla.br

${ }^{4}$ Universidade Federal de Pelotas, Departamento de Matemática e Estatística, Pelotas, Rio Grande do Sul, Brazil. gustavo.fialho@ufpel.edu.br

* Corresponding author: lidianegomes31@gmail.com
} 
variability of the species germplasm using effective crop breeding methods. Studies this nature are fundamental for conscious use of genetic resources and adoption of sustainable strategies to manage common bean cultivation (Rodrigues et al., 2002).

The estimation of genetic parameters such as coefficients of genotypic variation and heritability allows knowing the genetic variability existing in the studied population. In addition, heritability provides support for estimating the expected genetic progress by selection, even before it is carried out, which optimizes the choice of breeding strategies (Matos Filho et al., 2014).

Therefore, it is of great importance to estimate genetic parameters in common bean under competition, mainly to basic characteristics for grain yield, which have been the target of the main breeding programs. It is also noteworthy that such estimates can be influenced by different breeding methods, by type of genetic material used, by different environment conditions, by assessment time and crop phenological stage (Martins et al., 2016).

In this context, this study aimed to estimate the genetic parameters in nine characteristics of 20 common bean genotypes under dayflower interference, since these information are rare in the literature and essential for the development of improved cultivars under weed plants competition.

\section{MATERIALAND METHODS}

Twenty common bean genotypes (P. vulgaris $\mathrm{L}$.) were used, five commercial cultivars and fifteen regional genotypes belonging to the work collection of the Vegetal Analysis Laboratory from Department of Agronomy of the Center of Agricultural Sciences and Engineering from Federal University of Espírito Santo (CCAE-UFES) (Table 1).

The experiment was carried out in 2015/2016 agricultural year, in a greenhouse at Department of Agronomy at the Center of Agricultural Sciences and Engineering from Federal University of Espírito Santo (UFES), municipality of Alegre - ES (Latitude - $20^{\circ} 45^{\prime}$, Longitude - $\left.41^{\circ} 32^{\prime}\right)$. It was performed in a factorial scheme ( 2 x 20); with two levels of dayflower, presence and absence, and twenty bean genotypes, in a completely randomized design, with three replications, totaling forty treatments and 120 experimental units. The polyethylene pots used were $8 \mathrm{~L}$ containing $8.5 \mathrm{~kg}$ of a medium texture Red Latossol, collected at 0 to $20 \mathrm{~cm}$ depth, located at the experimental area of CCAE-UFES from Rive - Alegres/ES district.

The results of the chemical and physical analyses of the soil were as follows: $\mathrm{pH}\left(\mathrm{H}_{2} \mathrm{O}\right), 6 ; \mathrm{P}\left(\mathrm{mg} \mathrm{dm}^{-3}\right), 10 ; \mathrm{K}$ $\left(\mathrm{mg} \mathrm{dm}^{-3}\right), 83 ; \mathrm{S}\left(\mathrm{cmol} \mathrm{dm}^{-3}\right), 6 ; \mathrm{Ca}\left(\mathrm{cmol} \mathrm{dm}^{-3}\right), 1.5 ; \mathrm{Mg}$ $\left(\mathrm{cmol} \mathrm{dm}^{-3}\right), 0.4 ; \mathrm{Al}\left(\mathrm{cmol} \mathrm{dm}^{-3}\right), 0.3$; base saturation (\%),
66.0; $\mathrm{B}\left(\mathrm{mg} \mathrm{dm}^{-3}\right), 0$ and $21 ; \mathrm{Cu}\left(\mathrm{mg} \mathrm{dm}^{-3}\right), 2.0 ; \mathrm{Fe}\left(\mathrm{mg} \mathrm{dm}^{-3}\right)$, 90; $\mathrm{Mn}\left(\mathrm{mg} \mathrm{dm}^{-3}\right), 47 ; \mathrm{Zn}\left(\mathrm{mg} \mathrm{dm}^{-3}\right), 2.6$; and $3.10 \mathrm{~kg}$ organic matter dag ${ }^{-1}$. The textural components were $67 \%$ sand, $6 \%$ silt and $27 \%$ clay. Chemical corrections were dispensed with, since the soil presented favorable conditions for cultivation.

The weed plant used was dayflower, planting by stem sections with 3 nodes, at $5 \mathrm{~cm}$ depth and 2 sections per pot at the edges ones. Simultaneously, 5 bean seeds also was planted, $5 \mathrm{~cm}$ away from dayflower at $3 \mathrm{~cm}$ depth. At 10 days after planting, thinning was performed to remain only 2 bean plants per pot. To ensure competition, the weed plant propagule and the number of plants per pot (common beans $\mathrm{x}$ dayflower) was defined in a previous study already published by this team. For more information of the complete and detailed methodology see Gomes $e t$ al. (2017).

The pots were irrigated after planting and subsequently to irrigation followed according to evapotranspiration need of the crop, according to the pot capacity methodology (Casaroli \& Lier, 2008).

The following characters were evaluated: average stem diameter (ASD), average plant length (APL), number of pods per pot (NPP), number of locules per pot (NLP), number of grains per pod (NGP), percentage of empty locule $(\% \mathrm{EL}=$ (number of empty loci)/(total locus) $\mathrm{x} 100)$ (\% EL), total grains per pot (TGP), total grain weight per pot (TGW) and average grain weight (average grain weight $=($ grain biomass $) /($ number of grains $)(A G W)$.

The data obtained were subjected to variance analysis, adopting the following statistical models (Cruz et al., 2014) for joint analysis: $\mathrm{Y}_{\mathrm{ijk}}=\mu+\mathrm{g}_{\mathrm{i}}+\mathrm{t}_{\mathrm{j}}+\mathrm{gt}_{\mathrm{ij}}+\varepsilon_{\mathrm{ijk}}$. Where: $\mathrm{Y}_{\mathrm{ijk}}$ : is the observation of the $i$-th genotype in the $j$-th level of dayflower and $\mathrm{k}$-th repetition; $\mu$ : is the general average of the test; $\mathrm{g}_{\mathrm{i}}$ : is the effect of the $\mathrm{i}$-th genotype $(\mathrm{i}=1,2, \ldots, \mathrm{g})$, considered random with $\mathrm{g}_{\mathrm{i}} \sim \mathrm{NID}\left(0, \sigma_{\mathrm{g}}^{2}\right)$; $\mathrm{t}_{\mathrm{j}}$ is the effect of the $j$-th level of dayflower $(j=1,2)$, considered fixed; $g_{i j}$ : is the effect of the interaction of $i$-th genotype on the $j$-th level of dayflower, considered random with $\mathrm{gt}_{\mathrm{ij}} \sim$ $\operatorname{NID}\left(0, \sigma_{\mathrm{gt}}^{2}\right)$; and $\varepsilon_{\mathrm{ijk}}$ : experimental error, considered random $\varepsilon_{\mathrm{ijk}} \sim \operatorname{NID}\left(0, \sigma_{\mathrm{a}}^{2}\right)$. For individual analysis: $\mathrm{Y}_{\mathrm{ij}}=\mu+\mathrm{g}_{\mathrm{i}}+\varepsilon_{\mathrm{ij}}$; where: $Y_{i j}$ : is the observation of the $i-$ th genotype in the $j-$ th repetition; $\mu$ : general average of the test; $g_{i}$ : effect of the $\mathrm{i}$-th genotype $(\mathrm{i}=1,2, \ldots, \mathrm{g})$, considered random $\mathrm{g}_{\mathrm{i}} \sim$ $\operatorname{NID}\left(0, \sigma_{\mathrm{g}}^{2}\right) ; a_{\mathrm{ij}}$ : experimental error, considered random and $\varepsilon_{\mathrm{ij}} \sim \operatorname{NID}\left(0, \sigma_{\mathrm{a}}^{2}\right)$.

The genetic parameters and their estimators were analyzed for each agronomic characteristic, using the following expressions (Cruz et al., 2014) for joint analysis: genetic variance $\mathrm{Vg}=\frac{\mathrm{QMG}-\mathrm{QMR}}{\mathrm{rt}}$; interaction variance $\mathrm{Vgt}=\frac{\mathrm{QMGT}-\mathrm{QMR}}{\mathrm{r}\left[\frac{\mathrm{t}}{(\mathrm{t}-1)}\right]}$; residual variance $\mathrm{Ve}=$ 
QMR; heritability among genotypes averages $\mathrm{h}^{2}=100 \times \frac{\mathrm{Vg}}{\frac{\mathrm{QMG}}{\mathrm{rt}}} ;$ genotypic correlation through environments $\operatorname{rgloc}=\frac{\mathrm{Vg}}{(\mathrm{Vg}+\mathrm{Vgt})} ;$ coefficient of genotypic variation $\mathrm{CVg}=100 \times \frac{\mathrm{Vg}^{1 / 2}}{\mu}$; coefficient of environmental variation $\mathrm{CVe}=100 \times \frac{\mathrm{Ve}^{1 / 2}}{\mu}$; coefficient of variation $\mathrm{CVr}=\frac{\mathrm{CVg}}{\mathrm{CVe}}$; accuracy $\left[\right.$ Acur $\left.=\left(\mathrm{h}^{2}\right)^{1 / 2}\right]$ where: $\mathrm{QMG}=$ Mean square of genotypes; $\mathrm{QMGT}=$ Mean square of genotype $\mathrm{x}$ dayflower interaction; $\mathrm{QMR}=$ Mean square of residue; $r$ = number of repetitions; and $t=$ number of dayflower levels.

For individual analysis the following parameters were evaluated: genetic variance: $\frac{\mathrm{QMG}-\mathrm{QMR}}{\mathrm{r}}$; environmental variance $\quad \mathrm{Ve}=\frac{\mathrm{QMR}}{\mathrm{r}} ; \quad$ average heritability $\mathrm{h}^{2}=100 \times \frac{\mathrm{Vg}}{(V g+V e)}$; coefficient of genotypic variation $\mathrm{CVg}=100 \times \frac{\mathrm{Vg}^{1 / 2}}{\mu}$ coefficient of environmental variation $\mathrm{CVe}=100 \times \frac{\mathrm{Ve}^{1 / 2}}{\mu}$; coefficient of variation $\mathrm{CVr}=\frac{\mathrm{CVg}}{\mathrm{CVe}}$; accuracy $\left[\right.$ Acur $\left.=\left(\mathrm{h}^{2}\right)^{1 / 2}\right]$; where: $\mathrm{QMG}=$ Mean square of genotypes; $\mathrm{QMR}=$ Mean square of residue; and $\mathrm{r}=$ number of repetitions. Statistical-genetic analyzes were performed using Genes software (Cruz, 2013).

\section{RESULTS AND DISCUSSION}

There was a significant interaction of genotypes by environments (coexistence and absence of dayflower) for TGW and AGW, however, after unfolding of this variation source it was noted that interaction was due to differential behavior only of the regional cultivars. For commercial cultivars (BRS Pontal, BRS Pérola, BRS Ametista, BRS Estilo and BRS Agreste) in all studied characteristics, the ranking of the genotypes remained the same, both in absence and presence of dayflower competition (Table 2).

Analyzing regional and commercial materials, all characteristics were significant. However, for Regional vs. Commercial only AGW was significant. This can be explained because some regional materials have characteristics of Andean origin, where seeds are large with an average weight of 100 seeds over $40 \mathrm{~g}$ (Ribeiro et al., 2014).

There was a significant effect of genotype $\mathrm{x}$ dayflower interaction, for TPG and AGW, it is noteworthy that these are linked to crop production and are considered targets in breeding programs. Probably, such interaction is due to cultivars type III produce greater number of branches, therefore, greater number of pods per plant, responding differently as

Table 1: Genotypes, origin and growth habits of common bean (P. vulgaris L.), belonging to the Department of Plant Production of CCAE-UFES

\begin{tabular}{lcc}
\hline Genotype & Origin & Growth habits \\
\hline BRS Pontal (Biofortificada) & Commercial & Indeterminate \\
BRS Pérola & Commercial & Indeterminate \\
BRS Ametista & Commercial & Indeterminate \\
BRS Estilo & Commercial & Indeterminate \\
BRS Agreste (Biofortificada) & Commercial & Indeterminate \\
Carioca Comum & Regional & Indeterminate \\
Manteigão & Regional & Determined \\
Mulatinho & Regional & Indeterminate \\
Mulato & Regional & Indeterminate \\
Preto 90 dias & Regional & Indeterminate \\
Preto & Regional & Indeterminate \\
Preto Jalo & Regional & Determined \\
Carioca Pintadinho & Regional & Determined \\
Carioca preto & Regional & Determined \\
Corujinha & Regional & Determined \\
Rosinha Carioca & Regional & Determined \\
Mulato Manteigão & Regional & Indeterminate \\
Amendoim & Regional & Indeterminate \\
Vermelho 1 & Regional & Indeterminate \\
Vermelho 2 & Regional & Indeterminate \\
\hline
\end{tabular}




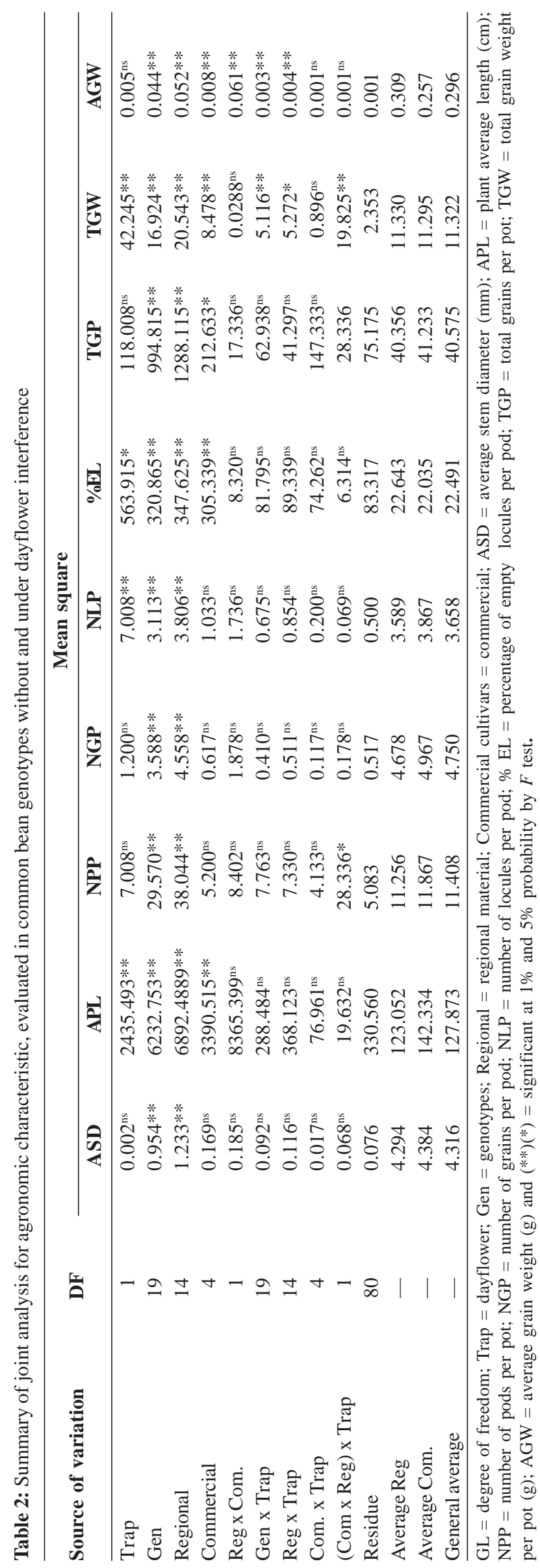

the competition levels with weed changes. It should also note that, TPG and AGW are quantitative characters controlled by many genes and strongly influenced by environment (Hamawaki et al., 2012).

The accuracy (Table 3 ) observed in the joint analysis was greater than 0.90 for all characteristics, except for $\%$ EL (0.87), which gives high experimental precision to the study. Still in this context and ensuring good statistical inference, in order to achieve the aforementioned accuracy, the $\mathrm{F}$ values for cultivars must be equal to or greater than 5.26, as recommended by Steel \& Torrie (1980).

Heritability is one of the most important genetic parameters, as it expresses the fraction of phenotypic variation of an inheritable nature, that is, can be used in a selection (Matos Filho et al., 2014). The estimated heritability coefficients ranged from $76.033 \%$ to $97.222 \%$ for \% EL and AGW, respectively. It shows the high heritability of all variables analyzed $\left(h^{2}>0.7\right)$, resulting in a considerable presence of genetic components in the expression of the studied characters, indicating largest proportion of observed phenotypic variation is due to genetic differences. Alves (2016) also found high heritabilities for common bean grain weights that ranged from 85.2 to $96.8 \%$. These results agree with our finding. Indicating that there is facility of selecting lines of beans with more grain weights.

The CVs indicated, in general, a good precision of the experiment. For ASD, a CV magnitude was lower than $10 \%$, while APL, NPP, NGP, NLP, TGW and AGW were lower than $20 \%$. The $\mathrm{CV}_{\mathrm{e}}$ is the residual standard deviation expressed as the general test average, and the precision level which experiment was conducted. It is known that attributes controlled by several genes and very influenced by environment, the $\mathrm{CV}_{\mathrm{e}}$ magnitudes are higher. Highest values of $\mathrm{CV}_{\mathrm{e}}$ were estimated for the percentage of empty locules and total grains per pot, indicating such quantitative characteristics and greatly influenced by environmental factors.

The average genotypic correlation of genetic materials among environments $\left(\mathrm{r}_{\text {gloc }}\right)$ indicates reliability of ordering the best genotypes in the tested environments. Significant changes were observed, due to high magnitude of $r_{\text {gloc }}$ ranging from 0.862 for TGW and 1.00 for NGP and TGP. The estimated genotypic correlations were of greater magnitude for the characters studied, indicating that genetic factors have greater influence on determining these correlations than environmental factors. Correlations of a genetic nature among characters are of great importance when it is desired to practice selection in a given character and when wants to predict response in another one correlated to the first. 


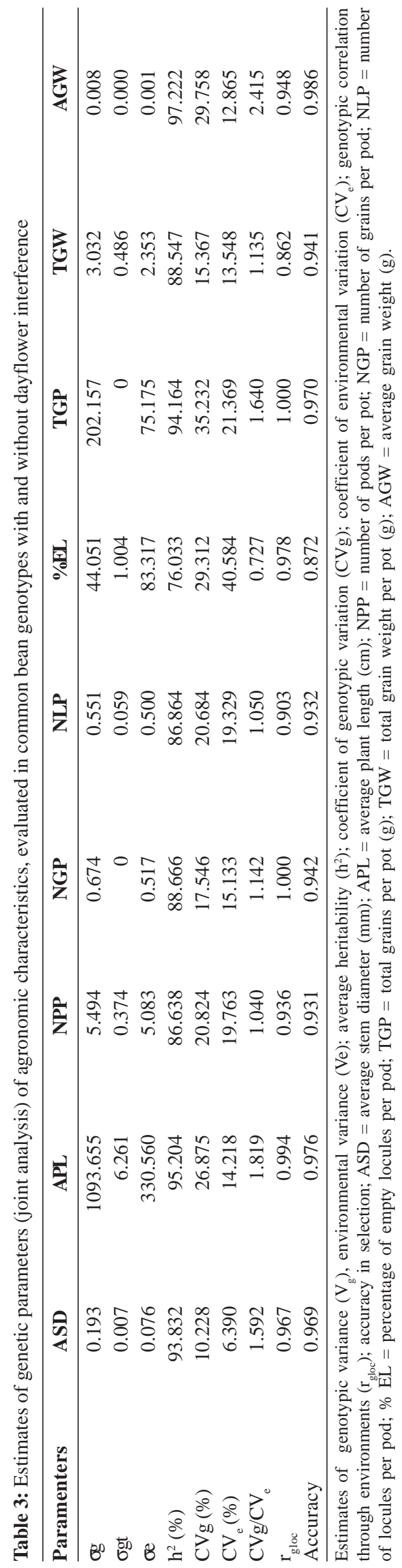

According to the individual variance analysis (Table 4), the bean genotypes obtained different performance for all characteristics analyzed when they were not intervened by dayflower. Similar results were found by Coelho et al. (2010), using 24 common bean cultivars, which 20 are landrance and 4 are commercial. The authors highlighted that stem thickness, number of pods per plant; number of grains per pod; number of locule per pod and weight of 100 grains obtained significant effect when subjected to tests in two years of cultivation and are effective to distinguish materials. Regional cultivars present significant effect $(\mathrm{F}<0.01)$ for all characters under study, shows high genetic variability among accessions.

In contrast, in commercial cultivars the significant effect was only for $\% \mathrm{EL}$, which shows similar performance for the other characters analyzed. Borém et al. (2017) state the narrowing of genetic basis in the development of elite materials, such as BRS Pérola, BRS Pontal, BRS Agreste, BRS Estilo and BRS Ametista cultivars due to the high degree of kinship between them. For this reason, a group of genotypes with low genetic divergence tends to respond in a similar way when sharing the same environment.

When analyzing the averages among regional and commercial materials in dayflower absence, very similar results are noted for the variables studied, except for APL, TGW and AGW. These differences are explained by high variability present in regional genotypes. These materials have very different characteristics, for example the presence of larger grains in genotypes such as Manteigão, Preto Jalo, Corujinha, Mulato Manteigão and Amendoim. This fact resulted in high averages of TGW and AGW.

Higher average for stem length in commercial cultivars is justified since they all present indeterminate growth habit. In this sense, these plants continued their vegetative growth even after flowering, which does not occur in genotypes with determined habits. Six of the fifteen regional genotypes have a determined habit, that is, they usually bloom and mature in a shorter period and stop their vegetative growth (Alves, 2016).

There is genetic variability among bean genotypes under dayflower interference (Table 4), this is evidenced by significance observed for all variables under study at $1 \%$ and $5 \%$ probability by $\mathrm{F}$ test. As already mentioned, most of this variation is due to high variability among accessions of regional genotypes. When observing their performance, there is a significant difference for all characteristics. On the other hand, performance of commercial cultivars remained uniform for most characteristics, excepting APL and TGP. This can be explained by breeding process in which these cultivars were exposed, which often leads to genetic narrowing by successive selection cycles (Carneiro et al., 2015). 
Table 4: Summary of individual variance for agronomic characteristics, evaluated in common bean genotypes without and under dayflower interference

\begin{tabular}{|c|c|c|c|c|c|c|c|c|c|c|}
\hline \multirow{2}{*}{ SV } & \multirow{2}{*}{ DF } & \multicolumn{9}{|c|}{ Mean square (without dayflower) } \\
\hline & & ASD & APL & NPP & NGP & NLP & $\% \mathbf{E L}$ & TGP & TGW & AGW \\
\hline Gen & 19 & $0.564 * *$ & $2963.335 * *$ & $24.122 * *$ & $1.525^{* *}$ & $1.469 * *$ & $230.730 * *$ & $416.978 * *$ & $5.982 * *$ & $0.016^{* *}$ \\
\hline Regional & 14 & $0.727 * *$ & $3352.725 * *$ & $31.127 * *$ & $1.889 * *$ & $1.714 * *$ & $227.562 * *$ & $560.451 * *$ & $6.622 * *$ & $0.019 * *$ \\
\hline C. Com & 4 & $0.077^{\mathrm{ns}}$ & $1394.488 * *$ & $4.900^{\mathrm{ns}}$ & $0.233^{\mathrm{ns}}$ & $0.667^{\mathrm{ns}}$ & $299.481 * *$ & $18.900^{\mathrm{ns}}$ & $2.567^{\mathrm{ns}}$ & $0.003^{\mathrm{ns}}$ \\
\hline Reg x Com & 1 & $0.238^{\mathrm{ns}}$ & $3787.257 * *$ & $2.939^{\mathrm{ns}}$ & $1.606^{\mathrm{ns}}$ & $1.250^{\mathrm{ns}}$ & $0.069^{\text {ns }}$ & $0.672^{\mathrm{ns}}$ & $10.682 *$ & $0.024 * *$ \\
\hline Residue & 40 & 0.079 & 244.036 & 5.133 & 0.617 & 0.517 & 67.521 & 32.850 & 1.550 & 0.002 \\
\hline Average of regional & - & 4.276 & 118.781 & 11.778 & 4.556 & 3.333 & 24.679 & 39.644 & 10.972 & 0.302 \\
\hline Averages of C. Com. & - & 4.422 & 137.129 & 11.267 & 4.933 & 3.667 & 24.600 & 39.400 & 9.997 & 0.255 \\
\hline \multirow[t]{2}{*}{ General Average } & - & 4.313 & 123.368 & 11.650 & 4.650 & 3.417 & 24.659 & 39.583 & 10.728 & 0.290 \\
\hline & & \multicolumn{9}{|c|}{ Mean square (with dayflower) } \\
\hline Gen & 19 & $0.482 * *$ & $3557.902 * *$ & $13.211 * *$ & $2.473 * *$ & $2.319 * *$ & $171.931^{\mathrm{ns}}$ & $640.775 * *$ & $16.058 * *$ & $0.031 * *$ \\
\hline Regional & 14 & $0.622 * *$ & $3907.887 * *$ & $14.248 * *$ & $3.181 * *$ & $2.946 * *$ & $209.403^{*}$ & $768.962 * *$ & $19.193 * *$ & $0.038^{* *}$ \\
\hline C. Com & 4 & $0.109^{\mathrm{ns}}$ & $2072.988 * *$ & $4.433^{\mathrm{ns}}$ & $0.500^{\mathrm{ns}}$ & $0.567^{\mathrm{ns}}$ & $80.120^{\mathrm{ns}}$ & $341.067 *$ & $6.808 \mathrm{~ns}$ & $0.006^{* *}$ \\
\hline $\operatorname{Reg} \times$ Com & 1 & $0.014^{\mathrm{ns}}$ & $4597.775 * *$ & $33.800 *$ & $0.450^{\mathrm{ns}}$ & $0.556^{\mathrm{ns}}$ & $14.566^{\mathrm{ns}}$ & $45.000^{\mathrm{ns}}$ & $9.171^{\mathrm{ns}}$ & $0.038^{* *}$ \\
\hline Residue & 40 & 0.073 & 417.084 & 5.033 & 0.417 & 0.483 & 99.113 & 117.500 & 3.156 & 0.001 \\
\hline Averages of regional & - & 4.311 & 127.324 & 10.733 & 4.800 & 3.844 & 20.608 & 41.067 & 11.689 & 0.317 \\
\hline Averages of C. Com. & - & 4.347 & 147.540 & 12.467 & 5.000 & 4.067 & 19.470 & 43.067 & 12.592 & 0.259 \\
\hline Geral Average & - & 4.320 & 132.378 & 11.167 & 4.850 & 3.900 & 20.324 & 41.567 & 11.915 & 0.303 \\
\hline
\end{tabular}

Gen = genotypes; C. Regional = landrace cultivars; C. Com = commercial cultivars and $(* *)(*)=$ significant at $1 \%$ e $5 \%$ of probability by $\mathrm{F}$ test. ASD $=$ average stem diameter $(\mathrm{mm}) ;$ APL $=$ average length per plant $(\mathrm{cm}) ; \mathrm{NPP}=$ number of pods per pot; NGP = number of grains per pod; NLP = number of locules per pod; $\%$ EL = percentage of empty locules per pod; TGP = total grains per pot; TGW = total grain weight per pot $(\mathrm{g})$; $\mathrm{AGW}=$ average grain weight $(\mathrm{g})$ 
Landrace and commercial cultivars differed regarding APL, TGW and NGP. These differences were expected since the test presents genotype of regional material and commercials with different growth habits (determined and indeterminate) and cultivars with varying grains sizes, mainly between genotypes of regional material. These results are reflected when analyzing the general averages between the two groups; and it is noted that APL was $147.540 \mathrm{~cm}$ and $127.324 \mathrm{~cm}$ for commercial genotypes and regional material, respectively.

As for the variation in NGV, one of the most important components in grain productivity, Gomes et al. (2017) also report that the coexistence of common bean plants with dayflower reduced the number of grains per plant, in addition to the number of pods and the weight of the grains. The authors emphasize that coexistence with weeds, especially in the first three weeks after emergence is enough to reduce the number of grains per pod and consequently the production. The variation observed for this character is due to the large number of genotypes used, showing significant genetic differences between them. The existing genetic variability caused variations on performance of cultivars in terms of number of grains per pod, showing that some genotypes are more sensitive when competing to environment resources.

In a breeding process, the higher the expression level of genetic variability regarding to environment, that is, presence of high heritability presented for interested characters, the greater estimated genetic gains for next generation (Avijala et al., 2015).

The coefficients of variation (Table 5) ranged from 6.530 to 33.323 , giving good accuracy to the estimates of this test. Genotypes present high genetic variability, evidenced mainly by landrace cultivars. Similar results were found by Ribeiro et al. (2009) in a study with 185 recombinant inbred lines of common beans. The authors observed significant variability for several agronomic characteristics, indicating the possibility of genetic gains in additional selection cycles. For all characters evaluated, genotypic variance was higher than environmental. This fact reveals that difference among materials consists mainly of its genetic basis. In this case, characteristics such as APL, NPP, \% EL, TGP and TGW stood out, which reinforces the idea that the presented phenotype suffers low environmental influence.

The average coefficient of heritability $\left(\mathrm{h}^{2} \%\right)$ was expressive for all characters evaluated, ranging from 67.353 to 94.139 for NGP and TGP, respectively. High values of heritability for the studied characteristics indicate additive genetic variance, lower environment variation and lower genotype and environment interaction. In addition, it assumes that a possible selection will be effective in a breeding program (Costa et al., 2010). These results corroborate with Coimbra et al. (1999) who found expressive heritability ( $>0.5$ ) for characters linked to yield in thirty-two genotypes of black beans such as: number of pod per plant, number of grains per pod and weight of one thousand grains.

The accuracy among genetic values ranged from 0.821 for the number of empty locules to 0.970 for the total grains per pot, which attests high precision in the selection. Accuracy is the main component of genetic progress and can be changed to maximize the gain. This is done by increasing the experimentation, keeping the same size in the experiment, but changing the number of plots or repetitions (Torres et al., 2015).

Values of coefficients of genotypic variation $\left(\mathrm{CV}_{\mathrm{g}}\right)$ ranged from 10.863 to 33.451 ; while coefficients of environmental variation $\left(\mathrm{CV}_{\mathrm{e}}\right)$ ranged from 6.530 to 33.341 . It is noted, however, that $\mathrm{CV}_{\mathrm{e}}$ values were lower than $\mathrm{CV}_{\mathrm{g}}$ for most of characters, which denotes good environmental control, efficiency in the experimental design and high variability among genotypes under study.

Coefficient of environmental variation of NGP, \% EL and TGP were higher than genotypic one, which reflected in ratio $\mathrm{CV}_{\mathrm{g}} / \mathrm{CV}<1$. Ratios $\mathrm{CVg} / \mathrm{CV}>1$ were observed for ASD (1.664), APL (2.140), NPP(1.285), TGP(2.310), TGW (1.021) and AGW (1.614) indicating that selection of these characters is favorable in terms of more immediate genetic gains (Cruz et al., 2014). The Table 5 shows the estimates of genetic parameters of nine quantitative characteristic evaluated in 20 common bean genotypes under dayflower interference.

Initially, it is noticed that variation observed among genotypes is predominantly to genetic causes $\left(\mathrm{V}_{\mathrm{g}}\right)$ than environmental ones $\left(\mathrm{V}_{\mathrm{e}}\right)$. This fact is proven due to high magnitudes of heritability presented by most of the evaluated characteristics. Only for NPP and \% EL herbability is $<0.7$, which is considered an average value. Avijala et al. (2015) state that characteristics with low heritability tend to hamper selection process, due to great environment influence. DMP, APL, NGP and AGW, heritabilities were greater than 0.85 proving that for these variables the selection would be optimized. It is worth noting that the greater heritability the greater genetic contribution to the total variability, which is desirable in a breeding program.

The coefficient of environmental variation $\left(\mathrm{CV}_{\mathrm{e}}\right)$ is low for most of the evaluated characters, which proves that there is a high genetic variation among cultivars and that environmental action on them is low, even under competition stress. The presence of wide variability among genotypes was expected, since genetic constitutions of different origins, characteristics and levels of improvement were evaluated. On the other hand, expressive $\mathrm{CV}_{\mathrm{e}}$ was observed for \% EL (48.985) which shows that there is a 


\begin{tabular}{|c|c|c|c|c|c|c|c|c|c|}
\hline \multicolumn{10}{|c|}{ WITHOUT DAYFLOWER } \\
\hline Parameters & ASD & APL & NPP & NGP & NLP & $\% \mathbf{E L}$ & TGP & TGW & AGW \\
\hline $\mathrm{Vg}$ & 0.216 & 1036.230 & 8.665 & 0.424 & 0.399 & 53.347 & 175.867 & 1.691 & 0.006 \\
\hline Ve & 0.026 & 81.345 & 1.711 & 0.206 & 0.172 & 22.507 & 10.950 & 0.517 & 0.001 \\
\hline $\mathrm{h}^{2}(\%)$ & 89.087 & 92.721 & 83.508 & 67.353 & 69.861 & 70.328 & 94.139 & 76.598 & 89.420 \\
\hline $\operatorname{CVg}(\%)$ & 10.863 & 27.101 & 24.992 & 14.295 & 18.955 & 29.596 & 33.451 & 11.852 & 24.830 \\
\hline $\mathrm{CV}_{\mathrm{e}}(\%)$ & 6.530 & 12.663 & 19.448 & 16.888 & 21.038 & 33.323 & 14.480 & 11.604 & 15.383 \\
\hline $\mathrm{CVg} / \mathrm{CV}$ & 1.664 & 2.140 & 1.285 & 0.846 & 0.901 & 0.888 & 2.310 & 1.021 & 1.614 \\
\hline Accuracy & 0.944 & 0.963 & 0.914 & 0.821 & 0.836 & 0.839 & 0.970 & 0.875 & 0.946 \\
\hline \multicolumn{10}{|c|}{ WITHDAYFLOWER } \\
\hline $\mathrm{Vg}$ & 0.183 & 1163.601 & 3.071 & 0.921 & 0.821 & 36.763 & 217.154 & 5.346 & 0.012 \\
\hline Ve & 0.024 & 139.028 & 1.678 & 0.139 & 0.161 & 33.038 & 39.167 & 1.052 & 0.001 \\
\hline h2 (\%) & 88.295 & 89.327 & 64.672 & 86.901 & 83.594 & 52.668 & 84.720 & 83.557 & 97.563 \\
\hline $\operatorname{CVg}(\%)$ & 9.926 & 26.791 & 16.328 & 19.998 & 23.567 & 29.422 & 35.883 & 19.780 & 34.939 \\
\hline $\mathrm{CV}_{\mathrm{e}}(\%)$ & 6.247 & 15.428 & 20.091 & 13.309 & 17.826 & 48.985 & 26.078 & 14.910 & 10.027 \\
\hline $\mathrm{CVg} / \mathrm{CV}_{\mathrm{e}}$ & 1.589 & 1.737 & 0.813 & 1.503 & 1.322 & 0.601 & 1.376 & 1.327 & 3.485 \\
\hline Accuracy & 0.940 & 0.945 & 0.804 & 0.932 & 0.914 & 0.726 & 0.920 & 0.914 & 0.988 \\
\hline
\end{tabular}

Estimates of genotypic variance $\left(\mathrm{V}_{\mathrm{g}}\right)$, environmental variance $\left(\mathrm{V}_{\mathrm{e}}\right)$, average heritability $\left(\mathrm{h}^{2}\right)$, coefficient of genetic variation $(\mathrm{CV})$, coefficient of variation $(\mathrm{CV})$ and accuracy in selection. ASD $=$ average stem diameter $(\mathrm{mm}) ; \mathrm{APL}=$ average plant length $(\mathrm{cm}) ; \mathrm{NPP}=$ number of pods per pot; NGP = number of grains per pod; NLP $=$ number of locules per pod; \% EL = percentage of empty locules per pod;

$\mathrm{TGP}=$ total grains per pot; TGW $=$ total grain weight per pot $(\mathrm{g}) ; \mathrm{AGW}=$ average grain weight $(\mathrm{g})$. 
high genotype x environment interaction. It can be explained once $\% \mathrm{EL}$ is a quantitative characteristic, related to many genes, therefore in a stress situation, the competition with dayflower was very influenced by environment.

Heritability estimates together with coefficient of genotypic variation $\left(\mathrm{CV}_{\mathrm{g}}\right)$ allow a better view on genetic advance to be expected with selection. Vieira (2006) point out that when aim to assess the real situation of a character, it is important to analyze $\mathrm{CV}_{\mathrm{g}}$ together with $\mathrm{CV}_{\mathrm{e}}$ through $\mathrm{CV}_{\mathrm{g}} / \mathrm{CV}_{\mathrm{e}}$ relationship. When heritability is greater than $80 \%$, the ratio described above will be higher than the unit. Obtaining values close to or higher than unit shows that there is a favorable situation for selection (Cruz et al., 2014).

The coefficient of genotypic variation $\left(\mathrm{CV}_{\mathrm{g}}\right)$ indicates great genetic variation among studied characteristics. These estimates ranged from 9.926 (APL) to 35.883 (TGP), with average grain weight and total grains per pot having the highest coefficients. This result was expected due to the range of genotypes and genetic origin under study. Knowledge of $\mathrm{CV}_{\mathrm{g}}$ is important because it indicates the variation range of a character and its use in the selection process.

The ratio between coefficients of genotypic and environmental variation $\left(\mathrm{CV}_{\mathrm{g}} / \mathrm{CV}_{\mathrm{e}}\right)$ was greater than unit in 7 of the 9 variables evaluated. These same characteristics showed high values of heritability, indicating that most of the variation observed is of a genetic nature. Cruz et al. (2014), state that when heritability is greater than $80 \%$, the ratio $\left(\mathrm{CV}_{\mathrm{g}} / \mathrm{CV}_{\mathrm{e}}\right)$ will be above the unit. These testifications allow us to affirm a very favorable situation to select characteristics of agronomic importance of common beans such as NGP, TGP and $\mathrm{AGW}$. The authors reiterate that $\mathrm{CV}_{\mathrm{g}} / \mathrm{CVe}$ ratio can be used as an indicator of the ease degree in selecting progenies for each character (Avijala et al., 2015).

The NGP and \% EL presented $\mathrm{CV}_{\mathrm{g}} / \mathrm{CV}_{\mathrm{e}}$ estimates below the unit indicating that the selection process requires criterious methods and statistical procedures with enough sensitivity (Torres et al., 2015).

The accuracy is between 0.726 for $\%$ EL and 0.988 for AGW when the genotypes were subjected to dayflower interference, ensuring the hypothesis of being successful in breeding programs using these genetic materials.

\section{CONCLUSIONS}

Under competition with dayflower, the 20 common bean genotypes studied showed great genetic variability regarding most of the characteristics evaluated.

There are great possibilities for success in genetic improvement programs for common beans aiming to increase the weight of grains and other characteristics in conditions of competition with weed plants.

\section{ACKNOWLEDGMENT}

To FAPES for granting the scholarship and supporting research, to Federal University of Espírito Santo (UFES) and to Graduate Program in Genetics and Breeding. Conflict of interest. The authors declare that they have no conflict of interest.

\section{REFERENCES}

Alves LP (2016) Caracterização morfoagronômica e molecular de feijão comum. Dissertação de mestrado. Universidade Federal do Espírito Santo, Alegre. 65p.

Avijala MF, Bhering LL, Peixoto LA, Cruz CD, Carneiro PCS, Cuambe CE \& Zacarias A (2015) Evaluation of cassava ('Manihot esculenta' Crantz) genotypes reveals great genetic variabilityand potential selection gain. Australian Journal of Crop Science, 9:940-947.

Borém A, Miranda VG \& Fritsche-Neto R (2017) Melhoramento de plantas. $7^{\mathrm{a}}$ ed. Viçosa, editora UFV. 543p.

Carneiro JES, Paula Junior TJ \& Borém A (2015) Feijão: do plantio à colheita. Viçosa, editora UFV. 384p.

Casaroli D \& Lier QJV (2008) Critérios para determinação da capacidade de vaso. Revista Brasileira Ciência do Solo, 32:59-66.

Costa RB, Resende MDV, Gonçalves PS, Roa RAR \& Feitosa KCO (2010) Predição de parâmetros e valores genéticos para caracteres de crescimento e produção de látex em progênies de seringueira. Bragantia, 69:49-56.

Coelho CMM, Zílio M, Souza C \& Guidolim AF (2010) Características morfo-agronômicas de cultivares crioulas de feijão comum em dois anos de cultivo. Semina: Ciências Agrárias, 31:1177-1186.

Coimbra JLM, Guidolin AF \& Carvalho FIF (1999) Parâmetros genéticos do rendimento de grãos e seus componentes com implicações na seleção indireta em genótipos de feijão preto. Ciência Rural, 29:01-06.

CONAB- Companhia Nacional de Abastecimento (2020) Safra de feijão 2018/2019. Available in: <www.conab.gov.br > Accesed on: October $22^{\text {nd }}, 2020$.

Cruz CD, Regazi AJ \& Carneiro PCS (2014) Modelos biométricos Aplicados ao Melhoramento Genético. $3^{\circ}$ ed. Viçosa, editora UFV. $514 \mathrm{p}$.

Cruz CD (2013) GENES: software package for analysis in experimental statistics and quantitative genetics. Acta Scientiarum, $35: 271-276$.

FAOSTAT Statistics Database (2020) Food and Agriculture Organization of the United Nations. Available at: <http:// www.fao.org/faostat/en/\#data/QC/visualize>. Accessed on: October $22^{\text {nd }}, 2020$.

Gomes LS, Dalvi LP, Altoé SC, Rocha LJFN \& Oliveira FL (2017) Competition with spreading dayflower (Commelina diffusa L.) can affect the agronomic characteristics and mineral content of common bean grains. Ciencia e Investigacion Agraria, 44:121126.

Hamawaki OT, Sousa LB, Romanato FN, Nogueira APO, Santos Júnior CD \& Polizel AC (2012) Genetic parameters and variability in soybean genotypes. Comunicata Scientiae, 3:7683.

Lorenzi H, Nicolai M, Bianchi MA, Inoue MH, Correia NM, Christoffoleti PJ, Vidal R, Victoria Filho R, Oliveira Junior RS \& Guimarães SC (2014) Manual de identificação e controle de plantas daninhas. $7^{\circ}$ ed. Nova Odessa, editora Plantarum. 384p. 
Martins SM, Melo PGS, Faria LC, Souza TSPO, Melo LC \& Pereira HS (2016) Genetic parameters and breeding strategies for high levels of iron and zinc in Phaseolus vulgaris L. Genetics and Molecular Research, 2:01-14.

Matos Filho CHA, Gomes RLF, Freire Filho FR, Rocha MM, Lopes ACA \& Nunes JAR (2014) Herança de caracteres relacionados à arquitetura da planta em feijão-caupi. Ciência rural, 44:599604

Prolla IRD, Barbosa RG, Veeck APL, Augusti PR, Silva LP, Ribeiro ND \& Emanuelli T (2010) Cultivar, harvest year, and storage conditions affecting nutritional quality of common beans (Phaseolus vulgaris L.). Ciência e Tecnologia de Alimentos, 30:96-102.

Ribeiro ND, Domingues LS, Gruhn EM, Zemolin AEM \& Rodrigues JA (2014) Desempenho agronômico e qualidade de cozimento de linhagens de feijão de grãos especiais. Revista Ciência Agronômica, 45:92 100.
Ribeiro EH, Pereira MG, Coelho KS \& Freitas Júnior SP (2009) Estimativas de parâmetros genéticos e seleção de linhagens endogâmicas recombinantes de feijoeiro comum (Phaseolus vulgaris L.). Revista Ceres, 56:580-590.

Rodrigues LS, Antunes IF, Teixeira MG \& Siela JB (2002) Divergência genética entre cultivares locais e cultivares melhoradas de feijão. Pesquisa Agropecuária Brasileira, 37:1275-1284.

Steel RGD \& Torrie JH (1980) Principies and Procedures of Statistics. $2^{\circ}$ ed. Nova Iorque, editora McGraw Hill. 633p.

Tavares CJ, Jakelaitis A, Rezende BPM \& Cunha PCR (2013) Fitossociologia de plantas daninhas na cultura do feijão. Revista Brasileira Ciências Agrárias, 8:27-32.

Torres FE, Sagrilo E, Teodoro PE, Ribeiro LP \& Cargnelutti Filho A (2015) Número de repetições para avaliação de caracteres em genótipos de feijão-caupi. Bragantia, 74:161-168.

Vieira R (2006) Cultura do feijão. $2^{\circ}$ ed. Viçosa, editora UFV. $146 \mathrm{p}$. 